\title{
МЕТОДИКА ОЦЕНКИ НАЛОГОВОЙ НАГРУЗКИ ОРГАНИЗАЦИЙ ОТРАСЛИ ГАЗОСНАБЖЕНИЯ
}

Аннотация: Объектом настоящего исследования является методология оценки налоговой нагрузки хозяйствующих субъектов отрасли газоснабжения, а также собственно налоговое бремя на сектор экономики, в рамках которого осуществляется производство и распределение газообразного топлива. Формальный подход к оценке налоговой нагрузки организаций сферы газоснабжения, предполагающий простое установление размера соотношения общей суммы налогов, подлежащих уплате в бюджет, и объёма совокупного дохода, не обеспечивает информативности результата расчёта. Цель данной работы, таким образом, заключается в создании и обосновании методики объективного установления уровня налоговой нагрузки газоснабжающих компаний. Методологическую базу данной работы составили следующие методы: дедукция, индукция, анализ, синтез, сравнение, обобщение, математическое моделирование. Содержание статьи служит обоснованием вывода, заключающегося в том, что объективная оценка налоговой нагрузки юридических лии отрасли газоснабжения предполагает установление степени тяжести фискального бремени. Достижение указанной цели требует решения ряда задач. Определение уровня налоговой нагрузки газоснабжающей компании подразумевает оценку влияния действий по выполнению обязанностей и реализации прав налогоплательщика на текущее и перспективное финансовое состояние хозяйствующего субъекта. Особую роль в алгоритме установления степени тяжести фискального гнёта на организации отрасли газоснабжения играет выявление меры негативного воздействия налоговых правоотношений на инвестиционную активность налогоплательщиков. Для оценки налогового бремени хозяйствующего субъекта среры газоснабжения представляют также значимость результаты сопоставления параметров его налоговой нагрузки с фискальной нагрузкой на отрасль в целом, на соответствующий субъект Российской Федерации, а также на отдельные газоснабжающие компании.

Ключевые слова: газоснабжение, газификация, налоговая нагрузка, инвестиционная активность, финансовая устойчивость, валовой региональный продукт, добавленная стоимость, выручка, совокупный доход, эффективность производственной деятельности.

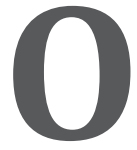
ценка налоговой нагрузки конкретных газотранспортных и газораспределительных организаций вне контекста налогового бремени на отрасль газоснабжения в целом представляется несостоятельной. Различие регионов России по уровню газификации, технологии газоснабжения потребителей и параметрам спроса на услуги компаний сферы энергообеспечения обусловливает существенную разницу между характеристиками финансового состояния отдельных хозяйствующих субъектов. Реализация единых правил налогообложения, установленных нормативно-правовыми актами, оказывает неодинаковое воздействие на финансовое положение организаций отрасли. В данном контексте, представляется объективным мнение Е.В. Чипуренко, в соответствии с которым налоговая нагрузка как пара- 
метр деятельности организации отражает не столько перечень подлежащих уплате налогов, сколько воздействие налоговых правоотношений на финансовую устойчивость налогоплательщика. ${ }^{1}$

Величина числителей коэффициентов налогового бремени хозяйствующих субъектов, значение которых приведено в таблице 1 , соответствует совокупной сумме налогов, начисленной в течение отчётного периода. Предлагаемый алгоритм оценки налоговой нагрузки организаций отрасли газоснабжения, таким образом, имеет существенное отличие от методики, разработанной Федеральной налоговой службой РФ. Согласно Концепции системы планирования выездных налоговых проверок, утверждённой Приказом ФНС России от 30.05.2007 № ММ-3-06/333@, показатель налоговой нагрузки определяется как соотношение общей суммы уплаченных налогов и объёма выручки хозяйствующего субъекта. ${ }^{2}$ Использование показателя начисленной суммы налогов как альтернативы совокупного объёма платежей, осуществлённых с целью снижения налоговой задолженности, позволяет получать сравнительно более точные результаты оценки налогового бремени организаций. Установление фактической степени тяжести налогового гнёта подразумевает рассмотрение объёма денежных средств, объективно подлежащих изъятию из производственно-торгового обо-

\footnotetext{
1 Чипуренко Е. В. Налоговая нагрузка предприятия: анализ, расчёт, управление. М.: Налоговый вестник, 2008. C. 15-19.

2 Общедоступные критерии самостоятельной оценки рисков для налогоплательщиков, используемые налоговыми органами в процессе отбора объектов для проведения выездных налоговых проверок: приложение № 2 к Приказу ФНС России от 30.05.2007 № ММ-3-06/333@: URL: http:/www.nalog.ru (дата обращения: 02.08.2013).
}

рота фирмы в пользу бюджета, в качестве абсолютного показателя налоговой нагрузки. Предлагаемая в настоящей статье методика определения уровня налоговой нагрузки исключает влияние нарушений налогоплательщиком финансовой дисциплины на искомые величины. Аргументом в пользу обоснованности представленной позиции служит мнение Е. А. Кировой, согласно которому оценка налоговой нагрузки путём соотнесения суммы, внесённой в бюджет, и величины выручки заведомо допускает нерепрезентативность рассчитываемого показателя. Значение коэффициента, исчисленного таким образом, как правило, не включает некоторой части задолженности организации по налогам. ${ }^{3}$ Корректное отражение степени тяжести налогового гнёта показателями, рассчитанными в соответствии с предлагаемым алгоритмом, обеспечивается также благодаря соблюдению принципа временной определённости исходных данных. В рамках описываемой методики оценки налоговой нагрузки юридических лиц сумма налогов соотносится исключительно с величиной сопряжённых с ними доходов.

Как свидетельствуют данные, представленные в таблице 1, показатели налоговой нагрузки газоснабжающих организаций различных регионов России сопоставимы.

Согласно результатам анализа степени тяжести налогового гнёта, проведённого коэффициентным методом, налоговая нагрузка дальневосточных компаний соответствует уровню налогового бремени хозяйствующих субъектов других регионов.

\footnotetext{
Бутов Д. В. Налоговая нагрузка: расчёт и законное снижение // Планово-экономический отдел. 2011. № 5. URL: http://www. profiz.ru/peo/5_2011/nalogovaia_ nagruzka/ (дата обращения: 06.08.2013).
} 
Значения показателей налоговой нагрузки организаций отрасли газоснабжения по данным за 2011 г, процентов

\begin{tabular}{|c|c|c|c|c|}
\hline \multicolumn{1}{|c|}{$\begin{array}{c}\text { Показатель налоговой } \\
\text { нагрузки }\end{array}$} & \multicolumn{3}{|c|}{ Наименование организации } \\
\cline { 2 - 5 } & $\begin{array}{c}\text { ОАО “Влади- } \\
\text { мироблгаз” }\end{array}$ & $\begin{array}{c}\text { ОАО “Ом- } \\
\text { скоблгаз” }\end{array}$ & $\begin{array}{c}\text { ОАО “Хаба- } \\
\text { ровсккрайгаз” }\end{array}$ & $\begin{array}{c}\text { ОАО “Даль- } \\
\text { трансгаз” }\end{array}$ \\
\hline $\begin{array}{l}\text { Соотношение суммы начислен- } \\
\text { ных налогов и совокупного дохо- } \\
\text { да, включающего операционные и } \\
\text { внереализационные доходы }\end{array}$ & 18,29 & 19,04 & 19,84 & 18,71 \\
\hline $\begin{array}{l}\text { Соотношение суммы начисленных } \\
\text { налогов и выручки от всех видов } \\
\text { деятельности }\end{array}$ & 19,69 & 19,40 & 20,36 & 20,37 \\
\hline $\begin{array}{l}\text { Соотношение суммы начисленных } \\
\text { налогов и добавленной стоимости, } \\
\text { созданной за отчётный период }\end{array}$ & 40,73 & 53,82 & 74,59 & 56,59 \\
\hline
\end{tabular}

В то время как показатели налоговой нагрузки газоснабжающих организаций Дальнего Востока приблизительно равны показателям налоговой нагрузки хозяйствующих субъектов, функционирующих на территории западной части России, уровень рентабельности внутри отрасли существенно варьируется. Данные, представленные в таблице 2, свидетельствуют о том, что ОАО «Хабаровскрайгаз» и ОАО «Дальтрансгаз» функционируют значительно менее эффективно, чем компании Центрального федерального округа и Сибири.

Показатели рентабельности активов и капитала ОАО «Владимироблгаз» и ОАО «Омскоблгаз» кратно превышают значение показателей рентабельности ОАО «Хабаровсккрайгаз». Деятельность ОАО «Дальтрансгаз» убыточна.

Установленный факт неравномерности налогового гнёта, оказываемого на отрасль газоснабжения, обусловливает необходимость выявления уровня взаимосвязи между макро- и микроэкономическими показателями налоговой нагрузки газотранспортных и газораспределительных компаний. В таблице 3 приведены данные, отражающие количественное выражение взаимозависимости между налоговой нагрузкой на добавленную стоимость, создаваемую отдельными газоснабжающими организациями, общеотраслевым и региональным уровнем налогового бремени. Использование суммы добавленной стоимости в качестве знаменателя коэффициента налоговой нагрузки конкретных хозяйствующих субъектов обеспечивает сопоставимость индивидуальных показателей налогового бремени с показателями налоговой нагрузки на валовую добавленную стоимость сектора экономики и валовой региональный продукт.

Как отражено в таблице 3, высокий уровень положительной корреляции между налоговым бременем на сферу энергообеспечения России и налоговой нагрузкой на добавленную стоимость, создаваемую отдельной организацией, демонстрируют ОАО «Владимироблгаз» и ОАО «Омскоблгаз».

Отсутствие взаимосвязи между налоговой нагрузкой дальневосточных газоснабжающих компаний и отраслевым 
Значения показателей рентабельности организаций

Таблица 2 отрасли газоснабжения, процентов

\begin{tabular}{|c|c|c|c|c|c|c|c|c|}
\hline \multirow{3}{*}{$\begin{array}{c}\text { Показатель } \\
\text { рентабельности }\end{array}$} & \multicolumn{8}{|c|}{ Наименование организации } \\
\hline & \multicolumn{2}{|c|}{$\begin{array}{l}\text { ОАО “Влади- } \\
\text { мироблгаз” }\end{array}$} & \multicolumn{2}{|c|}{$\begin{array}{c}\text { ОАО “Омскоб- } \\
\text { лгаз” }\end{array}$} & \multicolumn{2}{|c|}{$\begin{array}{c}\text { ОАО “Хаба- } \\
\text { ровсккрайгаз” }\end{array}$} & \multicolumn{2}{|c|}{$\begin{array}{l}\text { ОАО “Даль- } \\
\text { трансгаз” }\end{array}$} \\
\hline & 2010 г. & 2011 г. & 2010 г. & 2011 г. & 2010 г. & 2011 г. & 2010 г. & 2011 г. \\
\hline $\begin{array}{l}\text { ентабель } \\
\text { твенногс }\end{array}$ & 11,54 & 6,09 & 4,58 & 5,55 & 2,22 & $-2,46$ & $-13,39$ & $-12,29$ \\
\hline & 12,53 & 7,71 & 4,66 & 6,66 & 2,03 & 0,08 & $-8,33$ & $-6,95$ \\
\hline $\begin{array}{l}\text { льность внеобо- } \\
\text { активов }\end{array}$ & 14,90 & 9,09 & 7,48 & 10,47 & 3,89 & 0,16 & $-8,80$ & $-7,26$ \\
\hline Рента & 19,65 & & 3,90 & & 5,66 & & $-211,68$ & $-79,46$ \\
\hline $\begin{array}{l}\text { Рентабельность основ- } \\
\text { ных производственных } \\
\text { фондов }\end{array}$ & 15,93 & 9,62 & 8,77 & 12,11 & 5,21 & 0,17 & $-9,50$ & $-7,98$ \\
\hline $\begin{array}{l}\text { Рентабельность основ- } \\
\text { ной деятельности }\end{array}$ & 24,46 & 18,54 & 4,06 & 7,21 & 6,00 & 4,46 & $-75,84$ & $-50,36$ \\
\hline $\begin{array}{l}\text { Рентабельность перма- } \\
\text { нентного капитала }\end{array}$ & 14,86 & 9,07 & 6,60 & 9,79 & 3,82 & 0,17 & $-15,72$ & $-14,27$ \\
\hline $\begin{array}{l}\text { Норма чистой прибыли } \\
\text { в совокупном доходе }\end{array}$ & 12,30 & 6,26 & 1,17 & 1,37 & 0,79 & 0,78 & $-231,86$ & $-104,60$ \\
\hline
\end{tabular}

Таблица 3

Коэффициенты корреляции между макро- и микроэкономическими показателями налоговой нагрузки на отрасль газоснабжения

\begin{tabular}{|l|c|c|c|c|}
\hline \multicolumn{1}{|c|}{$\begin{array}{c}\text { Показатель налоговой } \\
\text { нагрузки }\end{array}$} & \multicolumn{4}{|c|}{ Наименование организации } \\
\cline { 2 - 5 } & $\begin{array}{c}\text { оАО “Вла- } \\
\text { димироб- } \\
\text { лгаз” }\end{array}$ & $\begin{array}{c}\text { оАО “Ом- } \\
\text { скоблгаз” }\end{array}$ & $\begin{array}{c}\text { оАО “Ха- } \\
\text { баровск- } \\
\text { крайгаз” }\end{array}$ & $\begin{array}{c}\text { оАО “Даль- } \\
\text { трансгаз” }\end{array}$ \\
\hline $\begin{array}{l}\text { Коэффициент корреляции между на- } \\
\text { логовой нагрузкой на добавленную сто- } \\
\text { имость, создаваемую организацией, и } \\
\text { общероссийским уровнем налоговой на- } \\
\text { грузки на сферу производства и распр- } \\
\text { деления электроэнергии, газа и воды }\end{array}$ & 0,95 & 0,99 & $-0,23$ & $-0,31$ \\
\hline $\begin{array}{l}\text { Коэффициент корреляции между на- } \\
\text { логовой нагрузкой на добавленную сто- } \\
\text { имость, создаваемую организацией, и } \\
\text { уровнем налоговой нагрузки на валовой } \\
\text { региональный продукт }\end{array}$ & 0,80 & $-0,52$ & 0,79 & $-0,51$ \\
\hline
\end{tabular}


налоговым бременем в общероссийском масштабе неоправданно, поскольку не связано с региональными налоговыми преференциями. В течение периода, которому соответствуют данные, использованные для установления уровня корреляции между макро- и микроэкономическими показателями налоговой нагрузки на отрасль газоснабжения, ОАО «Хабаровсккрайгаз» и ОАО «Дальтрансгаз» не пользовались территориальными налоговыми льготами. В данной связи налоговая нагрузка дальневосточных хозяйствующих субъектов представляется завышенной относительно уровня налогового бремени организаций, функционирующих на территории западной части страны. Условия налогообложения ОАО «Хабаровсккрайгаз» способствуют замедлению роста эффективности деятельности как собственно ОАО «Хабаровсккрайгаз», так и компании «Дальтрансгаз», осуществляющей магистральную транспортировку природного газа. Включение суммы, полученной компанией в результате применения специальной надбавки к тарифу на транспортировку газа, предназначенной для финансирования программ развития отрасли, в налоговую базу по налогу на прибыль организаций уменьшает инвестиционные возможности ОАО «Хабаровсккрайгаз». Снижение темпов газификации региона препятствует повышению эффективности функционирования как газотранспортного, так и газораспределительного хозяйствующего субъекта. Кроме того, изъятие части средств финансирования инвестиционных проектов в пользу бюджета является фактором увеличения продолжительности временного отрезка от начала строительства новых производственных фондов до начала уменьшения налоговой базы по налогу на прибыль организаций за счёт признания в налоговом учёте соответствующих расходов путём начисления амортизации. Данное обстоятельство существенно снижает финансовые выгоды организации, возникающие в рамках налоговых правоотношений. Сказанное свидетельствует в пользу справедливости мнения, выраженного Е. В. Чипуренко и заключающегося в том, что одним из элементов налоговой нагрузки хозяйствующего субъекта является совокупность правил налогообложения. ${ }^{4}$

Осуществление налогообложения на условиях равных сумм налоговых платежей в расчёте на один рубль дохода организаций западных и восточных регионов России при существенном различии уровня эффективности функционирования налогоплательщиков позволяет говорить о превентивном характере налогового давления на компании периферийных субъектов федерации.

В контексте вышесказанного, установление истинной степени тяжести налогового бремени юридических лиц отрасли газоснабжения предполагает принятие во внимание характера и уровня взаимозависимости показателей налоговой нагрузки и индикаторов инвестиционной активности хозяйствующих субъектов. В качестве характеристики инвестиционной деятельности организаций целесообразно использовать размер остатков средств, затраченных на создание незавершённых строительством объектов. Данная величина, с одной стороны, отражает объём капиталовложений хозяйствующего субъекта, с другой стороны, позволяет судить о скорости их оборачиваемости и темпах строительных работ.

\footnotetext{
4 Чипуренко Е. В. Налоговая нагрузка предприятия: анализ, расчёт, управление. М.: Налоговый вестник, 2008. C. $15-16$.
} 
DOI: $10.7256 / 1812-8688.2014 .3 .11394$

При цитировании этой статьи сноска на doi обязательна

Налогообложение природопользования

Таблица 4

Коэффициенты корреляции между величиной остатков средств, вложенных в незавершённое строительство, и показателями налоговой нагрузки организаций отрасли газоснабжения

\begin{tabular}{|c|c|c|c|c|}
\hline \multirow{2}{*}{$\begin{array}{c}\text { Показатель } \\
\text { налоговой } \\
\text { нагрузки }\end{array}$} & \multicolumn{4}{|c|}{ Наименование организации } \\
\hline & $\begin{array}{c}\text { ОАО “Влади- } \\
\text { мироблгаз” }\end{array}$ & $\begin{array}{l}\text { ОАО “Ом- } \\
\text { скоблгаз” }\end{array}$ & $\begin{array}{c}\text { ОАО “Хабаровск- } \\
\text { крайгаз” }\end{array}$ & $\begin{array}{c}\text { ОАО “Дальтран- } \\
\text { сгаз” }\end{array}$ \\
\hline $\begin{array}{l}\text { Соотношение суммы } \\
\text { начисленных налогов } \\
\text { и совокупного дохода, } \\
\text { включаюего опера- } \\
\text { ционные и внереали- } \\
\text { зационные доходы }\end{array}$ & 0,89 & $-0,15$ & $-0,76$ & 0,63 \\
\hline $\begin{array}{l}\text { Соотношение суммы } \\
\text { начисленных налогов } \\
\text { и добавленной стои- } \\
\text { мости, созданной за } \\
\text { отчётный период }\end{array}$ & 0,69 & $-0,59$ & $-0,90$ & 0,79 \\
\hline
\end{tabular}

В таблице 4 представлены показатели степени взаимозависимости между уровнем налоговой нагрузки и стоимостной оценкой незавершённого строительства.

Результаты анализа значений коэффициентов корреляции между показателями налоговой нагрузки и объёмом незавершённого строительства хозяйствующих субъектов свидетельствуют о том, что об устойчивой отрицательной взаимозависимости между налоговым бременем и уровнем инвестиционной активности можно говорить только в отношении ОАО «Хабаровсккрайгаз». Осуществление расходов, связанных с созданием основных производственных фондов, не способствует снижению налоговой базы по налогу на прибыль организаций до начала начисления амортизации по соответствующим объектам. Снижение остатков средств в незавершённом строительстве в результате окончания работ по возведению сооружений приводит к уменьшению налоговой базы по налогу на прибыль организаций вследствие роста совокупной суммы расходов налогоплательщика в части амортизационных отчислений. Влияние сокращения объёма незавершённого строительства на динамику общей суммы налогов, подлежащей внесению в бюджет, представляет собой фактор прямой взаимосвязи между остатками незавершённого строительства и уровнем налогового бремени хозяйствующего субъекта. Таким образом, отрицательная корреляция между стоимостной оценкой незавершённого строительства и показателями налоговой нагрузки свидетельствует о существенной обратной зависимости инвестиционной активности компании от степени тяжести налогового бремени. Подобное положение дел возможно при условии неоправданно высокого уровня налоговой нагрузки хозяйствующего субъекта. В свете сказанного, уменьшение налогового бремени ОАО «Хабаровсккрайгаз» имеет стратегическое 
значение для развития Дальневосточного федерального округа.

Выводы о необходимости снижения налоговой нагрузки газоснабжающих компаний восточных регионов России подтверждается также результатами анализа взаимосвязи между уровнем налогового бремени и интенсивностью осуществления хозяйствующими субъектами капиталовложений. В таблице 5 и таблице 6 представлены значения коэффициентов корреляции между показателями налоговой нагрузки организаций отрасли газоснабжения и характеристиками процессов производственного развития: коэффициентом устойчивости экономического роста и коэффициентом инвестиционной активности. Коэффициент устойчивости экономического роста отражает соотношение реинвестированной в течение отчётного периода суммы прибыли и среднегодовой величины собственного капитала. ${ }^{5}$ Размер коэффициента инвестиционной активности хозяйствующего субъекта соответствует частному от деления совокупной суммы освоенных в отчётном периоде инвестиций на стоимость активов фирмы.

Как свидетельствуют данные, приведённые в таблице 5 и таблице 6, в рамкахчетырёх принятых во внимание организаций обратная взаимозависимость между показателями налоговой нагрузки и уровнем инвестиционной активности свойственна только ОАО «Омскоблгаз» и ОАО «Хабаровсккрайгаз». ОАО «Владимироблгаз» демонстрирует положительную корреляцию между степенью тяжести налогового бремени и коэффициентами, характеризующими интенсивность производственного развития. Финансовое состояние ОАО «Дальтрансгаз» не предполагает прямой

5 Банк В. Р., Банк С. В., Тараскина А. В. Финансовый анализ: учеб. пособ. М.: Проспект, 2009. С. 142. взаимообусловленности динамики объёма капиталовложений и колебаний уровня налоговой нагрузки. Данное обстоятельство сопряжено с существенной зависимостью хозяйствующего субъекта от внешних источников финансирования. ${ }^{6}$

Различие уровня корреляции между налоговой нагрузкой на сферу энергообеспечения России и показателями налоговой нагрузки отдельных организаций отрасли газоснабжения (таблица 3) обусловливает необходимость установления структуры совокупной суммы налогов, подлежащих внесению в бюджет конкретными хозяйствующими субъектами. В данной связи представляется объективным высказанное рядом авторов (в частности, М. И. Литвиным, Д. В. Бутовым) мнение, согласно которому налоговая нагрузка организации как экономическая категория носит комплексный характер и включает, в числе прочего, состав совокупной суммы налогов, начисленной за отчётный период. ${ }^{7}$

В таблице 7 представлены показатели удельного веса налогов, предусмотренных законодательством, в общем объёме признанной в течение отчётного периода задолженности налогоплательщиков перед бюджетом.

Данные таблицы характеризуют налоговое бремя ОАО «Дальтрансгаз» как наиболее тяжёлое в рамках рассмотренной группы компаний. Доля налога на добавленную стоимость в совокупной сумме налогов, подлежащих уплате данным хозяйствующим субъектом, составляет почти 100\%. При этом в течение периода, приня-

\footnotetext{
6 Дальтрансгаз: [сайт]. URL: http://www.daltransgas.ru/ (дата обращения: 23.08.2013).

7 Бутов Д. В. Налоговая нагрузка: расчёт и законное снижение // Планово-экономический отдел. 2011. № 5. URL: http://www. profiz.ru/peo/5_2011/nalogovaia_ nagruzka/ (дата обращения: 06.08.2013).
} 
Коэффициенты корреляции между уровнем налоговой нагрузки на совокупный доход и показателями инвестиционной активности организаций отрасли газоснабжения

\begin{tabular}{|c|c|c|c|c|}
\hline \multirow{2}{*}{$\begin{array}{c}\text { Показатель } \\
\text { инестиционной } \\
\text { активности }\end{array}$} & \multicolumn{3}{|c|}{ Наименование организации } \\
\cline { 2 - 5 } & $\begin{array}{c}\text { оАО “Влади- } \\
\text { мироблгаз” }\end{array}$ & $\begin{array}{c}\text { ОАО “Омскоб- } \\
\text { лгаз” }\end{array}$ & $\begin{array}{c}\text { ОАО “Хаба- } \\
\text { ровсккрайгаз” }\end{array}$ & $\begin{array}{c}\text { ОАО “Даль- } \\
\text { трансгаз” }\end{array}$ \\
\hline $\begin{array}{l}\text { Коэффициент устойчиво- } \\
\text { сти экономического роста }\end{array}$ & 0,98 & $-0,95$ & $-0,62$ & - \\
\hline $\begin{array}{l}\text { Коэффициент инвестици- } \\
\text { онной активности }\end{array}$ & 0,87 & $-0,97$ & $-0,86$ & $-0,08$ \\
\hline
\end{tabular}

Коэффициенты корреляции между уровнем налоговой нагрузки на добавленную стоимость и показателями инвестиционной активности организаций отрасли газоснабжения

\begin{tabular}{|c|c|c|c|c|}
\hline \multirow[b]{2}{*}{$\begin{array}{c}\text { Показатель инвестици- } \\
\text { онной активности }\end{array}$} & \multicolumn{4}{|c|}{ Наименование организации } \\
\hline & $\begin{array}{l}\text { ОАО “Влади- } \\
\text { мироблгаз” }\end{array}$ & $\begin{array}{l}\text { ОАО “Омскоб- } \\
\text { лгаз” }\end{array}$ & $\begin{array}{c}\text { ОАО “Хаба- } \\
\text { ровсккрайгаз” }\end{array}$ & $\begin{array}{l}\text { ОАО “Даль- } \\
\text { трансгаз” }\end{array}$ \\
\hline $\begin{array}{l}\text { Коэффициент устойчиво- } \\
\text { сти экономического роста }\end{array}$ & 0,91 & $-0,65$ & $-0,77$ & - \\
\hline $\begin{array}{l}\text { Коэффициент инвестици- } \\
\text { онной активности }\end{array}$ & 0,72 & $-0,73$ & $-0,04$ & 0,56 \\
\hline
\end{tabular}

Средние показатели удельного веса отдельных налогов в совокупной сумме налогов, подлежащих внесению в бюджет организациями отрасли газоснабжения, процентов

\begin{tabular}{|l|c|c|c|c|}
\hline \multirow{2}{*}{\begin{tabular}{c}
\multirow{2}{*}{$\begin{array}{c}\text { Наименование } \\
\text { налога }\end{array}$} \\
\cline { 2 - 5 }
\end{tabular}} & $\begin{array}{c}|c| \\
\text { ОАО “Владими- } \\
\text { роблгаз” }\end{array}$ & $\begin{array}{c}\text { ОАо “Омскоб- } \\
\text { лгаз” }\end{array}$ & $\begin{array}{c}\text { оАо “Хаба- } \\
\text { ровсккрайгаз” }\end{array}$ & $\begin{array}{c}\text { оАо “Даль- } \\
\text { трансгаз” }\end{array}$ \\
\hline $\begin{array}{l}\text { Налог на добавлен- } \\
\text { ную стоимость }\end{array}$ & 64,07 & 86,17 & 74,93 & 96,04 \\
\hline $\begin{array}{l}\text { Налог на прибыль } \\
\text { организаций }\end{array}$ & 16,53 & 5,37 & 0,91 & - \\
\hline $\begin{array}{l}\text { Налог на имущество } \\
\text { организаций }\end{array}$ & 13,12 & 3,99 & 3,50 & 3,20 \\
\hline Прочие налоги & 6,27 & 4,47 & 20,65 & 0,76 \\
\hline
\end{tabular}


того во внимание для расчёта анализируемых показателей, ОАО «Дальтрансгаз» не получал прибыли. Таким образом, обложению налогом на добавленную стоимость фактически (с учётом применения налоговых вычетов) подвергаются только социально значимые расходы организации.

Изложенное обстоятельство, а также факт перманентной убыточности функционирования ОАО «Дальтрансгаз» обусловливают необходимость освобождения компании от обязанностей плательщика налога на добавленную стоимость. Данная преференция должна носить временный характер. Длительность её применения следует определять исходя из продолжительности периода достижения компанией «Дальтрансгаз» устойчивого финансового положения и финансовой самостоятельности.

В экономической литературе находит отражение мнение, в соответствии с которым уплата косвенных налогов не влияет на финансовое состояние хозяйствующих субъектов. К числу сторонников этого утверждения относятся, например, М. Н. Соболев $^{8}$ и О. Ф. Бочарова. ${ }^{9}$ Фундаментальные начала данной идеи содержатся в теории экономики предложения, в частности, в трудах А. Лаффера. ${ }^{10}$ Прикладное развитие неоклассическая концепция получила, в том числе, в форме методик определения уровня налоговой нагрузки организации, подразумевающих исключение суммы косвенных налогов из абсолютных и относительных показателей налогового бремени.

\footnotetext{
8 Бочарова О. Ф. Проблемы российской практики применения НДС в налогообложении добавленной стоимости // Налоги и финансовое право. 2012. № 3. С. 250.

9 Бочарова О. Ф. Проблемы российской практики применения НДС в налогообложении добавленной стоимости // Налоги и финансовое право. 2012. № 3. С. 252. 10 Капогузов Е. А. Политическая экономия налогообложения. Омск: Изд-во ОмГУ, 2006. С. 102-106.
}

Приверженность данному методологическому подходу выражают, в частности, О. Ф. Бочарова ${ }^{11}$ и М. Н. Крейнина. ${ }^{12}$ Однако, более соответствующей действительности представляется точка зрения, заключающаяся в рассмотрении налоговых правоотношений в целом в качестве фактора финансовой устойчивости налогоплательщика. Так Н. Л. Хантаева в обоснование данной позиции приводит факт того, что применение прямых надбавок к тарифам оказывает влияние на соотношение спроса и предложения на соответствующем рынке, способствуя тем самым отвлечению финансовых ресурсов из производственно-торгового оборота. ${ }^{13}$ Разделяя вышеизложенное мнение, Е. А. Капогузов подкрепляет его дополнительным аргументом. Финансовое состояние плательщиков косвенных налогов подвержено негативному воздействию необходимости внесения в бюджет существенной суммы платежей вне зависимости от фактического уровня эффективности функционирования. При этом Е. А. Капогузов считает, что по признаку источника выплат налог на добавленную стоимость близок к прямым налогам. ${ }^{14}$ И. А. Маслова категорично называет НДС прямым налогом. ${ }^{15}$ М. А. Ревякина

11 Бочарова О. Ф. Проблемы российской практики применения НДС в налогообложении добавленной стоимости // Налоги и финансовое право. 2012. № 3. С. 255.

12 Лавренчук Е. Н. Налоговый анализ // Управление экономическими системами: сетевой журнал. 2011. URL: http://www.uecs.ru/uecs-25-252010/item/309-2011-0325-09-54-14/ (дата обращения: 29.08.2013).

13 Хантаева Н. Л. Теоретические основы налогообложения. URL: http://knigi-uchebniki.com/naloginagooblojenie_720/nalogovaya-nagruzka-raspredelenie. html (дата обращения: 08.08.2013).

14 Капогузов Е. А. Политическая экономия налогообложения. Омск: Изд-во ОмГУ, 2006. С. 119.

15 Маслова И. А. Инфраструктурная концепция образования стоимости и распределения добавленной стоимости по группам экономических субъектов // Финансы и кредит. 2006. № 3. С. 46. 
DOI: $10.7256 / 1812-8688.2014 .3 .11394$

При цитировании этой статьи сноска на doi обязательна

Налогообложение природопользования

Таблица 8

Коэффициенты корреляции между показателями темпа роста выручки в сопоставимых ценах и уровнем налоговой нагрузки организаций отрасли газоснабжения

\begin{tabular}{|c|c|c|c|c|}
\hline \multirow[b]{2}{*}{$\begin{array}{c}\text { Показатель налоговой } \\
\text { нагрузки }\end{array}$} & \multicolumn{4}{|c|}{ Наименование организации } \\
\hline & $\begin{array}{l}\text { ОАО “Влади- } \\
\text { мироблгаз” }\end{array}$ & $\begin{array}{c}\text { ОАО “Омскоб- } \\
\text { лгаз” }\end{array}$ & $\begin{array}{c}\text { ОАО “Хаба- } \\
\text { ровсккрайгаз" }\end{array}$ & $\begin{array}{l}\text { ОАО “Даль- } \\
\text { трансгаз” }\end{array}$ \\
\hline $\begin{array}{l}\text { Соотношение суммы начис- } \\
\text { ленных налогов и совокуп- } \\
\text { ного дохода, включающего } \\
\text { операционные и внереализа- } \\
\text { ционные доходы }\end{array}$ & $-0,21$ & 0,47 & $-0,71$ & $-0,90$ \\
\hline $\begin{array}{l}\text { Соотношение суммы начис- } \\
\text { ленных налогов и выручки } \\
\text { от всех видов деятельности }\end{array}$ & $-0,25$ & 0,46 & $-0,67$ & $-0,69$ \\
\hline $\begin{array}{l}\text { Соотношение суммы начис- } \\
\text { ленных налогов и добавлен- } \\
\text { ной стоимости, созданной за } \\
\text { отчётный период }\end{array}$ & $-0,03$ & 0,05 & 0,28 & $-0,97$ \\
\hline
\end{tabular}

отмечает, что движение денежных средств в рамках финансово-хозяйственной деятельности организации играет не меньшую роль в определении её финансового состояния, нежели динамика показателей рентабельности и размер собственного капитала. ${ }^{16}$ Вопреки собственному утверждению о неподверженности финансового состояния организации влиянию процессов, сопряженных с реализацией прав и исполнением обязанностей плательщика налога на добавленную стоимость, О. Ф. Бочарова отмечает, что необходимость регулярного внесения в бюджет НДС обусловливает существенную зависимость компании от обеспеченности свободными денежными средствами. ${ }^{17}$ Вышеизложенные умозаключения позволяют

16 Карасёва И.М., Ревякина М. А. Финансовый менеджмент: учеб. пособ. М.: Омега-Л, 2008. С. 34.

17 Бочарова О. Ф. Проблемы российской практики применения НДС в налогообложении добавленной стоимости // Налоги и финансовое право. 2012. № 3. C. 252 . утверждать о целесообразности принятия во внимание причитающейся к внесению в бюджет суммы косвенных налогов при расчёте показателей налоговой нагрузки.

Вывод о влиянии правоотношений, связанных с уплатой налога на добавленную стоимость, на финансовое состояние налогоплательщика подтверждается результатами анализа взаимозависимости темпа роста доходов от основных видов деятельности и колебаний уровня налогового бремени организаций отрасли газоснабжения. В таблице 8 представлены коэффициенты корреляции между показателями налоговой нагрузки хозяйствующих субъектов и темпом роста их выручки, объём которой скорректирован на величину индекса-дефлятора.

Согласно данным, приведённым в таблице 8 , существенный уровень обратной взаимозависимости между темпом роста выручки и значением показателей налоговой нагрузки (а именно коэффициентов налоговой нагрузки на совокупный доход и нало- 
говой нагрузки на добавленную стоимость) свойственен только ОАО «Дальтрансгаз». Размер признаваемой в течение отчётного периода совокупной суммы задолженности ОАО «Дальтрансгаз» перед бюджетом практически тождественен величине начисляемого налога на добавленную стоимость (таблица 7). Следовательно, влияние налоговой нагрузки ОАО «Дальтрансгаз» на финансовое положение компании определяется главным образом движением денежных средств, связанным с исполнением обязанностей и реализацией прав плательщика НДС. Увеличение объёма выручки способствует росту совокупной суммы налоговых обязательств хозяйствующего субъекта. Характер зависимости динамики величины задолженности организации перед бюджетом от колебаний размера торгового оборота является фактором положительной корреляции между показателями налоговой нагрузки и темпом роста выручки. Таким образом, факт отрицательной корреляции между уровнем налогового бремени и скоростью увеличения доходов от основных видов деятельности даёт основание полагать выраженной обратную взаимозависимость производственного потенциала компании от степени тяжести налогового гнёта.

Данные об обратной взаимосвязи между темпом роста выручки и показателями налоговой нагрузки ОАО «Дальтрансгаз» заслуживают особого внимания ввиду первостепенной значимости увеличения объёмов производственно-коммерческого оборота для улучшения финансового состояния организации.

Сохранение размера тарифа на магистральную транспортировку газа на уровне, соответствующем правилам формирования цен на услуги организаций, являющихся плательщиками налога на добавленную стоимость, при условии пре- доставления ОАО «Дальтрансгаз» вышеуказанной налоговой льготы обеспечит компании поступление дополнительных денежных средств. В настоящий момент OАО «Дальтрансгаз» нуждается в существенном объёме финансовых ресурсов, что обусловлено необходимостью реализации инвестиционных проектов. При этом, как отмечает руководство компании, экономически обоснованная величина тарифа на транспортировку газа по эксплуатируемому ОАО «Дальтрансгаз» магистральному газопроводу кратно превышает фактически утверждённый размер. $^{18}$ Установленная статьёй 168 Налогового кодекса РФ норма, в соответствии с которой сумма налога на добавленную стоимость включается в цену товара (услуги, работы) ограничивает возможность повышения ликвидности ОАО «Дальтрансгаз» за счёт увеличения тарифа на транспортировку газа.

О низком уровне использования потенциала развития отрасли газоснабжения на Дальнем Востоке косвенно свидетельствует отсутствие взаимозависимости между налоговым бременем ОАО «Дальтрансгаз» и налоговой нагрузкой на валовой продукт региона (таблица 3). Среди трёх принятых во внимание газораспределительных организаций данной особенностью отличается только ОАО «Омскоблгаз». Компаниям «Владимироблгаз» и «Хабаровсккрайгаз» свойственна тесная взаимосвязь между налоговой нагрузкой на создаваемую добавленную стоимость и налоговой нагрузкой на валовой региональный продукт. Малое значение коэффициентов корреляции между показателями налогового бремени ОАО «Дальтрансгаз» и ОАО «Омскоблгаз» и налоговой нагрузкой Дальневосточного

\footnotetext{
18 Дальтрансгаз: [сайт]. URL: http://www.daltransgas.ru/ (дата обращения: 08.08.2013).
} 
DOI: $10.7256 / 1812-8688.2014 .3 .11394$

При цитировании этой статьи сноска на doi обязательна

Налогообложение природопользования

Таблица 9

\begin{abstract}
Показатели удельного веса добавленной стоимости, созданной газоснабжающими организациями, в величине валового регионального продукта соответствующих административно-территориальных образований за период с 2008 г. по 2011 г., процентов
\end{abstract}

\begin{tabular}{|l|c|c|c|c|}
\hline \multirow{2}{*}{$\begin{array}{c}\text { Наименование } \\
\text { организации }\end{array}$} & \multicolumn{4}{|c|}{ Отчётный период } \\
\cline { 2 - 5 } & $\mathbf{2 0 0 8}$ г. & $\mathbf{2 0 0 9}$ г. & $\mathbf{2 0 1 0}$ г. & $\mathbf{2 0 1 1}$ г. \\
\hline ОАО “Владимироблгаз” & 0,34 & 0,37 & 0,36 & 0,35 \\
\hline OАО “Омскоблгаз” & 0,07 & 0,09 & 0,07 & 0,07 \\
\hline OАО “Хабаровсккрайгаз” & 0,18 & 0,17 & 0,57 & 0,20 \\
\hline OАО “Дальтрансгаз” & 0,01 & 0,004 & 0,002 & 0,01 \\
\hline
\end{tabular}

федерального округа и Омской области соответственно сопряжено со сравнительно небольшим размером долей указанных организаций в экономике названных административно-территориальных образований. Коэффициенты соотношения стоимости, генерируемой ОАО «Владимироблгаз» и ОАО «Хабаровсккрайгаз», и величины регионального продукта Владимирской области и Хабаровского края соответственно кратно превышают размер удельного веса добавленной стоимости ОАО «Омскоблгаз» в валовой добавленной стоимости Омской области. Данное обстоятельство отражено в таблице 9.

Относительно низкий уровень оснащённости ОАО «Омскоблгаз» фондами, составляющими инфраструктуру снабжения населения и промышленных объектов природным газом, обусловливает функционирование компании в условиях жёсткой конкуренции с другими поставщиками сжиженного и природного газа. Удельный вес природного газа, транспортируемого ОАО «Омскоблгаз», в совокупном объёме природного газа, перемещаемого по территории Омской области, составляет порядка $15 \%{ }^{19}$ Подобное положение дел позволяет

19 Омскоблгаз: [сайт]. URL: http://www.e-disclosure. $\mathrm{ru} /$ portal/company.aspx?id=3903 (дата обращения: 15.08.2013). говорить об исключительно формальном статусе регионального монополиста, в качестве которого зарегистрирована компания «Омскоблгаз». При этом налоговое бремя ОАО «Омскоблгаз» соответствует уровню налоговой нагрузки организаций, пользующихся преимуществами ведущих субъектов рынка газоснабжения (таблица 1). Меры, направленные на ослабление налогового гнёта, в условиях которого функционирует ОАО «Омскоблгаз», должны способствовать повышению интенсивности процессов газификации Омской области. Рост уровня фондовооружённости юридического лица можно стимулировать посредством снижения ставки налога на имущество организаций. Таким образом, действие нормы Закона Омской области «0 налоге на имущество организаций», согласно которой отдельным категориям хозяйствующих субъектов предоставляется пониженная ставка налога на имущество организаций $\left(0,01 \%{ }^{20}\right.$ следует распространить на компании отрасли газоснабжения вне зависимости от даты их государственной регистрации. В указанном нормативном акте необходимо закре-

20 О налоге на имущество организаций: Закон Омской области от 21.11.2003 № 478-O3: URL: http://base. consultant.ru/regbase/cgi/online.cgi?req=doc; base=RLAW 148;n=69719 (дата обращения: 10.05.2013). 
пить правило, в соответствии с которым пониженная ставка налога на имущество организаций должна применяться только в отношении основных производственных средств, обеспечивающих сетевую транспортировку природного газа.

Изложенный материал демонстрирует преимущества предлагаемой методики оценки налоговой нагрузки организаций отрасли газоснабжения над алгоритмом, содержание которого исчерпывается расчётом соотношения общей суммы налогов, подлежащей внесению в бюджет, и величины базового показателя: совокупного дохода, выручки, добавленной стоимости. Установление степени тяжести налогового бремени хозяйствующего субъекта с учётом положения в отрасли, эффективности функционирования налогоплательщика, влияния налоговых правоотношений на его финансовое состояние позволяет не только объектив- но определить уровень фискальной нагрузки. Комплексный анализ взаимосвязи налогового бремени и финансового положения хозяйствующего субъекта даёт возможность установить направления совершенствования правил налогообложения газоснабжающих организаций.

Соответствие величины соотношения совокупной суммы налоговых обязательств и размера дохода отдельных газоснабжающих компаний среднеотраслевому значению данного коэффициента обусловливает необходимость применения индивидуального подхода к оценке налоговой нагрузки хозяйствующих субъектов. В качестве главного критерия степени тяжести налогового бремени организаций сферы газоснабжения следует рассматривать меру негативного воздействия налоговых правоотношений на текущее и перспективное финансовое состояние налогоплательщика.

\section{Библиография:}

1. Общедоступные критерии самостоятельной оценки рисков для налогоплательщиков, используемые налоговыми органами в процессе отбора объектов для проведения выездных налоговых проверок: приложение № 2 к Приказу ФНС России от 30.05.2007 № MM-3-06/333@: URL: http://www.nalog.ru (дата обращения: 02.08.2013).

2. О налоге на имущество организаций: Закон Омской области от 21.11.2003 № 478-03: URL: http://base.consultant.ru/regbase/cgi/online.cgi?req=doc;base=RLAW148;n=69719 (дата обращения: 10.05.2013).

3. Банк В. Р., Банк С. В., Тараскина А. В. Финансовый анализ: учеб. пособ. М.: Проспект, 2009. 352 c.

4. Бочарова О. Ф. Проблемы российской практики применения НДС в налогообложении добавленной стоимости // Налоги и финансовое право. 2012. № 3. С. 250-255.

5. Бутов Д. В. Налоговая нагрузка: расчёт и законное снижение // Планово-экономический отдел. 2011. № 5. URL: http://www. profiz.ru/peo/5_2011/nalogovaia_nagruzka/ (дата обращения: 06.08.2013).

6. Владимироблгаз: [сайт]. URL: http://www.vladoblgaz.ru/ (дата обращения: 11.04.2012).

7. Газпром: [сайт]. URL: http://www.gazprom.ru/production/projects/east-program/ (дата обращения: 28.03.2012). 
8. Государственный Комитет по статистике РФ: [сайт]. URL: http://www.gsk.ru/ (дата обращения: 15.06.2012).

9. Государственный Комитет по статистике РФ: [сайт]. URL: http://www.gsk.ru/ (дата обращения: 08.08.2013).

10. Дальтрансгаз: [сайт]. URL: http://www.daltransgas.ru/ (дата обращения: 25.06.2012).

11. Дальтрансгаз: [сайт]. URL: http://www.daltransgas.ru/ (дата обращения: 08.08.2013).

12. Капогузов Е. А. Политическая экономия налогообложения. Омск: Изд-во ОмГУ, 2006. 144 с.

13. Карасёва И. М., Ревякина М. А. Финансовый менеджмент: учеб. пособ. М.: Омега-Л, 2008. 335 c.

14. Лавренчук Е. Н. Налоговый анализ // Управление экономическими системами: сетевой журнал. 2011. URL: http://www.uecs.ru/uecs-25-252010/item/309-2011-03-2509-54-14/ (дата обращения: 29.08.2013).

15. Маслова И. А. Инфраструктурная концепция образования стоимости и распределения добавленной стоимости по группам экономических субъектов // Финансы и кредит. 2006. № 3. С. 46-54.

16. Омскоблгаз: [сайт]. URL: http://www.e-disclosure.ru/portal/company.aspx?id=3903 (дата обращения: 15.08.2013).

17. Хантаева Н. Л. Теоретические основы налогообложения. URL: http://knigi-uchebniki. com/nalogi-nagooblojenie_720/nalogovaya-nagruzka-raspredelenie.html (дата обращения: 08.08.2013).

18. Чипуренко Е.В. Налоговая нагрузка предприятия: анализ, расчёт, управление. М.: Налоговый вестник, 2008. 490 с.

19. Е.П. Ансимова Методика оценки налоговой отдачи организаций отрасли газоснабжения // Налоги и налогообложение. - 2012. - 8. - С. 8-19.

20. Антонова Е.В. Выбор методики определения налоговой нагрузки и налоговое планирование на предприятии // Налоги и налогообложение. - 2013. - 8. - С. 615-625. DOI: 10.7256/1812-8688.2013.8.8048.

21. Антонова Е.В. Выбор методики определения налоговой нагрузки на предприятии // Налоги и налогообложение. - 2013. - 5. - C. 350-363. DOI: 10.7256/18128688.2013.5.8770.

22. Е. П. Ансимова Методика оценки налоговых рисков организаций отрасли газоснабжения // Налоги и налогообложение. - 2012. - 3. - С. 58-65.

23. Бородина А.С. Оценка налоговой нагрузки производственного предприятия // Налоги и налогообложение. - 2011. - 9. - С. 5-14.

24. Агузарова Ф.С., Татрова Э.Т.. Влияние нефтегазовых доходов на формирование федерального бюджета Российской Федерации. // Налоги и налогообложение. - 2013. № 9. — C. 643-653. DOI: .10.7256/1812-8688.2013.9.9591.

25. Пиванова А. В.. Сравнительная характеристика правовового регулирования добычи нефти и газа на континентальном шельфе в федеративной республике бразилии и в российской федерации. // Тренды и управление. - 2013. - № 3. - C. 91-96. DOI: $.10 .7256 / 2307-9118.2013 .3 .6244$.

26. О.С. Иванов. Налогообложение нефтяной и газовой отрасли РФ и стран БРИКС (на примере России, Бразилии и Китая). // Национальная безопасность / nota bene. 2013. — № 2. — C. 277-293. DOI: .10.7256/2073-8560.2013.02.7. 


\section{References:}

1. Obshchedostupnye kriterii samostoyatel'noi otsenki riskov dlya nalogoplatel'shchikov, ispol'zuemye nalogovymi organami v protsesse otbora ob"ektov dlya provedeniya vyezdnykh nalogovykh proverok: prilozhenie № 2 k Prikazu FNS Rossii ot 30.05.2007 № MM-3-06/333@: URL: http://www.nalog.ru (data obrashcheniya: 02.08.2013).

2. O naloge na imushchestvo organizatsii: Zakon Omskoi oblasti ot 21.11.2003 № 478-0Z: URL: http://base.consultant.ru/regbase/cgi/online.cgi?req=doc;base=RLAW148;n=69719 (data obrashcheniya: 10.05.2013).

3. Bank V. R., Bank S. V., Taraskina A. V. Finansovyi analiz: ucheb. posob. M.: Prospekt, 2009. $352 \mathrm{s.}$

4. Bocharova O. F. Problemy rossiiskoi praktiki primeneniya NDS v nalogooblozhenii dobavlennoi stoimosti // Nalogi i finansovoe pravo. 2012. № 3. S. 250-255.

5. Butov D. V. Nalogovaya nagruzka: raschet i zakonnoe snizhenie // Planovo-ekonomicheskii otdel. 2011. № 5. URL: http://www. profiz.ru/peo/5_2011/nalogovaia_nagruzka/ (data obrashcheniya: 06.08.2013).

6. Vladimiroblgaz: [sait]. URL: http://www.vladoblgaz.ru/ (data obrashcheniya: 11.04.2012).

7. Gazprom: [sait]. URL: http://www.gazprom.ru/production/projects/east-program/ (data obrashcheniya: 28.03.2012).

8. Gosudarstvennyi Komitet po statistike RF: [sait]. URL: http://www.gsk.ru/ (data obrashcheniya: 15.06.2012).

9. Gosudarstvennyi Komitet po statistike RF: [sait]. URL: http://www.gsk.ru/ (data obrashcheniya: 08.08.2013).

10. Dal'transgaz: [sait]. URL: http://www.daltransgas.ru/ (data obrashcheniya: 25.06.2012).

11. Dal'transgaz: [sait]. URL: http://www.daltransgas.ru/ (data obrashcheniya: 08.08.2013).

12. Kapoguzov E. A. Politicheskaya ekonomiya nalogooblozheniya. Omsk: Izd-vo OmGU, 2006. $144 \mathrm{~s}$.

13. Karaseva I. M., Revyakina M. A. Finansovyi menedzhment: ucheb. posob. M.: Omega-L, 2008. $335 \mathrm{~s}$.

14. Lavrenchuk E. N. Nalogovyi analiz // Upravlenie ekonomicheskimi sistemami: setevoi zhurnal. 2011. URL: http://www.uecs.ru/uecs-25-252010/item/309-2011-03-25-0954-14/ (data obrashcheniya: 29.08.2013).

15. Maslova I. A. Infrastrukturnaya kontseptsiya obrazovaniya stoimosti i raspredeleniya dobavlennoi stoimosti po gruppam ekonomicheskikh sub"ektov // Finansy i kredit. 2006. № 3. S. 46-54.

16. Omskoblgaz: [sait]. URL: http://www.e-disclosure.ru/portal/company.aspx?id=3903 (data obrashcheniya: 15.08.2013).

17. Khantaeva N. L. Teoreticheskie osnovy nalogooblozheniya. URL: http://knigi-uchebniki.com/ nalogi-nagooblojenie_720/nalogovaya-nagruzka-raspredelenie.html (data obrashcheniya: 08.08.2013).

18. Chipurenko E.V. Nalogovaya nagruzka predpriyatiya: analiz, raschet, upravlenie. M.: Nalogovyi vestnik, 2008. 490 s.

19. E.P. Ansimova Metodika otsenki nalogovoi otdachi organizatsii otrasli gazosnabzheniya // Nalogi i nalogooblozhenie. - 2012. - 8. - C. 8-19. 
DOI: $10.7256 / 1812-8688.2014 .3 .11394$

20. Antonova E.V. Vybor metodiki opredeleniya nalogovoi nagruzki i nalogovoe planirovanie na predpriyatii // Nalogi i nalogooblozhenie. - 2013. - 8. - C. 615-625. DOI: 10.7256/18128688.2013.8.8048.

21. Antonova E.V. Vybor metodiki opredeleniya nalogovoi nagruzki na predpriyatii // Nalogi i nalogooblozhenie. - 2013. - 5. - C. 350-363. DOI: 10.7256/1812-8688.2013.5.8770.

22. E. P. Ansimova Metodika otsenki nalogovykh riskov organizatsii otrasli gazosnabzheniya // Nalogi i nalogooblozhenie. - 2012. - 3. - C. 58-65.

23. Borodina A.S. Otsenka nalogovoi nagruzki proizvodstvennogo predpriyatiya // Nalogi i nalogooblozhenie. - 2011. - 9. - C. 5-14.

24. Aguzarova F.S., Tatrova E.T.. Vliyanie neftegazovykh dokhodov na formirovanie federal'nogo byudzheta Rossiiskoi Federatsii. // Nalogi i nalogooblozhenie. - 2013. - № 9. - C. 643653. DOI: .10.7256/1812-8688.2013.9.9591.

25. Pivanova A. V.. Sravnitel'naya kharakteristika pravovovogo regulirovaniya dobychi nefti i gaza na kontinental'nom shel'fe $\mathrm{v}$ federativnoi respublike brazilii i v rossiiskoi federatsii. // Trendy i upravlenie. — 2013. — № 3. — C. 91-96. DOI: .10.7256/2307-9118.2013.3.6244.

26. O.S. Ivanov. Nalogooblozhenie neftyanoi i gazovoi otrasli RF i stran BRIKS (na primere Rossii, Brazilii i Kitaya). // Natsional'naya bezopasnost' / nota bene. — 2013. — № 2. - C. 277293. DOI: .10.7256/2073-8560.2013.02.7. 